Organization - OCB (2016a) and about 50\% of the Brazilian agricultural production go through, in some way, the cooperatives (OCB; 2016b). The professionalization of the Brazilian agricultural are part of a positive, but wide agenda that gathers strategies to preserve and improve the cooperative system, to face the competition, increase the integrity and economic viability to promote and value people. According to the management report of OCB (2016b), one of the challenges for the entity is to contribute for the professionalization of the management and the cooperative system govern.

It is each day more evident the pertinence the professionalized management of the cooperatives longing a different and strategic position, according with the Cooperative Organization of Paraná- OCEPAR (2016), due to the globalization of the business, increasing of competition and demand, together with the urgency of finding a new market.

In this context, with this job the aim was to analyze the strategies of the Human Resource Management adopted during the period of professionalization of the agricultural cooperatives, for this, it was used the Miles \& Snow typology strategy (1978; 1984). The approach was qualitative, with a descriptive type research and case study with three cooperatives from Paraná State. The agricultural industry was chosen to be one of the most dynamic and representatives for the Brazilian economy, being responsible for $33 \%$ of the gross domestic product (GDP), being $42 \%$ of the total exportation and 37\% of the jobs in 2015 (OCB; 2916b). There cooperatives are in the State of Parana, that according to OCEPAR (2016) shows the biggest number of agricultural cooperatives and cooperated of the country.

With this study, the intention is to contribute for the knowledge and debate about the professionalization of one of the most important organization forms in the Brazilian agricultural industry, that by its means, is one of the main pillars of the economy. Besides, it is needed to emphasize, the complexity of the management in cooperatives, because, according with Hansmann (1996), the managerial process of the cooperatives tend to not separate the property from the management, being the executives associated to the cooperative by law. In this way, cooperated are landowners and clients of their own organization, making it harder to rationalize the management, beyond the existent of diffused property that impacts on the perception of the importance of the professionalization of the Human Resource Management area acting.

\section{Agricultural Cooperatives}

The cooperativism can be understood as an association of people that together seek for the best for the group, by all means of values and mutual help, responsibility, democracy, equality, equity and solidarity, in other words, the associates search for honesty, transparency, social responsibility and concern about their own (OCB; 2016a). On the other hand, the Brazilian cooperatives running on the XXI century market go through a series of dilemmas and crisis, due to the commercial relations evolution and the need to obtain and maintain rentability on the capitalistic economy and a constant ideological consequence. Capitalistic values remain over the cooperation values, when in fact, the desire is to maintain the economic efficiency and the social efficacy together with the preservation of the fundamental doctrinaire principals, that guides the activity aims and provide economic advantages to their members (BIALOSKORSKI NETO; 
MARQUES, 1998; RECH, 2000; BIALOSKORSKI NETO; TRINDADE, 2012; BIALOSKORSKI NETO, 2013).

As far as the cooperative rationalize the expenses common to everyone making the results more efficient, it re-enforces the power of the bargain of the products towards the market uniting the financial and economic capacity of the members, eliminating the average of the selling process, reducing the cost of acquisition of the products of the cooperated usage and makes it possible to put the products and services with more accessible and competitive prices, and allows a quality control with efficiency on the products that are produced by he cooperated, instead of that individual control made by each cooperated. Even though the system is full of advantages, consumers and society, cooperatives present management problems due to their organizational structure, because in a context of pulverized ownership, in which several agents have the right to control, corporate governance problems arise from the fact that several owners wish to exercise control in a different way, due to divergence of interests (BIALOSKORSKI NETO, MARQUES, 1998; BIALOSKORSKI NETO, TRINDADE, 2012; BIALOSKORSKI NETO, 2013).

For Bialoskorski Neto \& Marques (1998) and Polonio (2004), the concept for agricultural cooperatives is defined as organizations formed by rural, agropastoral and fishing producers that have their means of production belonging to the cooperative, who receive or commercialize the joint production; as well as the industrialization, storage, and receipt of services such as technical, educational, and social assistance. Rech (2000) defines the agricultural cooperative as being a production placement cooperative type, that is, they dedicate themselves to the placement of the production of its associates in the best possible conditions of prices, regularity, and security.

In addition to the economic and administrative rationality required to achieve internal and external efficacy, as well as greater competitiveness in relation to noncooperative enterprises, principles such as democratic management and free adhesion have received severe criticism and pressure to reformulate them (JANK AND NASSAR, 1995; BERNARDO, 1996; ANTONIALLI, SOUKI, 2005). Rech (2000) argues that cooperatives that have remained in the market have moved from pure cooperation to large enterprises, i.e., the characteristics of cooperation have been replaced by centralized administrations, exercising power, and aggressive intervention in the market.

The changes happened, per Jank \& Nassar (1995) and Antonialli \& Souki, 2005), since many agricultural cooperatives are facing serious problems like the loss of the best producers for the non-cooperative companies. Moreover, criticisms appear in the sense of this model to present deficiencies in the administration that compromise the creation of competitive advantages and consequently the success in the market, being: slowness in the decision making due to the lack of consensus among cooperatives, low professionalization, centralization of power, remuneration of managers, which encourages wage-earning rather than participation as a producer, low participation of cooperative members in assemblies, and lack of planning and strategy knowledge to develop long-term planning (DE MASY, 1978; LAUSCHNER E SCHWEINBERGER, 1989; SCHULZE 1987; SILVA 2005; ANTONELLO, 1995; JANK; NASSAR, 1995; ANTONIALLI; SOUKI, 2005).

To win the competition, cooperatives must be efficient and this fact leads to the need for management improvement, cost reduction and staffing, and training and de- 
velopment for cooperatives in production and administrative activities. To solve these problems, more than two decades ago, sophisticated management models have emerged that require an internal administration that is well aligned with the needs of cooperatives, in this case complex, with no room for amateurism, printing criteria of efficiency and fidelity in the relationship with the Cooperate and, more importantly, prevent personal and political interests from influencing the decisions taken by the strategies chosen by cooperatives (ZYLBERSTAJN, 1994).

\section{Competitive Advantages and the Professional Management}

Considering the competitive profile of companies, competition may also have a strategic character when deliberated, carefully studied and rigorously weighted. The basic elements of strategic competition are: understanding of competitive behavior whose members interact continuously in the system, use of this understanding to predict how the competitive balance will change given a strategic move; Resources that can be invested constantly, even if the benefits of this investment appear in the long term; Ability to accurately predict risks and profits for investment to be justified, and last, but not least, willingness to act. On the contrary, natural competition, given as opportunistic - due to its moment-to-moment and evolutionary interactions - by the incremental process of low risk trials and errors, does not require predictions or involvements but rather adaptation. Its conservative nature does not exclude the possibility of obtaining effective and complex results, such as the development of the Human Resource Management. However, previously uncontrolled changes can cost time and even generations, failing to follow a rapidly evolving dynamic environment, i.e., there is no adaptation to competitors or competitors (HENDERSON, 1998; BARNEY; HESTERLY, 2007).

Barney and Hesterly (2007) argue that although many researchers agree that to survive and thrive a firm depends on the choice and implementation of a good strategy that provides a basis for gaining space and advantage in strong competition environments. The definition of strategy and what constitutes a good strategy. Strategy can be said as the theory of how to gain competitive advantage and a good strategy would be one that would in fact generate such desired advantages, that is, an efficient strategy. Ireland, et al (2014) argue that the company can only make sure that the strategy has resulted in one or more competitive advantages when competition efforts to duplicate the strategy fail or cease. In addition, organizations must understand that no competitive advantage has a permanent character, and its life time is determined by the ability of competitors to develop the skill needed to perform the duplication.

Per Hoskisson et al (2009), internal resource analysis and value chain evaluation aims to create a competitive advantage over competitors that leads to superior performance. Such analysis allows the discovery of what the company can do and, when compatible with what the company could do (from external analysis), allows the development of the intention, strategic mission, selection and implementation of its strategy. In relation to the resources, capacities, and competences essential to the creation of sustainable competitive advantage, the authors affirm that alone these variables do not have inherent value, but when used to perform certain activities that result in competitive advantage, they create value. The objective of the internal analysis by decision 
makers is to understand how best to leverage this unique group of resources and capabilities and to find managers who can make such decisions with a greater chance of success considering three conditions: uncertainty, complexity and conflicts Intraorganizational, as detailed in Table 1:

Table 1 - Conditions that affect the management decisions

\begin{tabular}{l|l|l}
\hline C & Uncertainty & Uncertainty is present about the characteristics of the industrial and \\
$\mathrm{O}$ & & general environments of the company and the needs of the custom- \\
$\mathrm{N}$ & & ers. \\
\cline { 2 - 3 } $\mathrm{D}$ & & Complexity \\
$\mathrm{T}$ & & Complexity results from the interrelationships between the condi- \\
$\mathrm{I}$ & & tions that shape a company. \\
\cline { 2 - 3 } $\mathrm{O}$ & Intraorganizational conflicts & Intraorganizational conflicts may exist in managers who make deci- \\
$\mathrm{N}$ & & sions as well as among those affected by decisions. \\
$\mathrm{S}$ & & \\
\hline
\end{tabular}

Source: Adapted from Hoskisson et al (2009, p. 81).

Many organizational capabilities are based on the transfer and exchange of information and knowledge through human capital. Companies that value the continued development of their professional skills are more likely to sustain a competitive advantage for longer than those who do not believe in the importance of education and training (HOSKISSON et al, 2009). In addition, a good reputation for employee treatment attracts outside professionals, which can increase the quality of the organization's intellectual capital.

Professionalization can be understood as the process of hiring professional administrators who bring experience to improve a specific area (BAÑEGIL PALACIOS, BARROSO MARTÍNEZ; TATO JIMENÉZ, 2013). Costa and Batista (2003) point out that the professionalization process happens when the separation between ownership and management is perceived more clearly. In the context of agricultural cooperatives, Zylbersztajn (1994, p. 31) states that the "complete separation of ownership and control is demanded by the presence of professionals hired in the market with experience in managing non-cooperative corporations."

The process of professionalization is also evolutionary and directed to the elevation of formality, also understood as development of the organizational structure, in which the professional manager must prevail to the patrimonial manager when characterizing functional rationality, delimitation of authority, requirements of qualification for occupation of positions and documentation of the administrative actions, per Fleury and Fleury (2001). The authors defend the idea of competition between organizations through professional competence, not only by product, by attracting and developing people with combinations of complex capabilities.

Davis and Bialoskorski Neto (2010) emphasize the importance of an adequate selection of candidates for cooperative management, considering the compatibility of the profile of managers with that of the organization. Recruitment care should be greater than what is usually done, as candidates must meet the co-op's needs as well as understand the complexity of their structures and processes. Cooperatives risk losing their true purpose if they do not develop a sound management culture. Thus, they emphasize the need to implement a cooperative education program in order to help man- 
agers act in a context that is very different from that of a good number of managers, that is, companies whose only purpose is profit and capital.

Miles and Snow (1984) argue that successful companies have a consistent strategy supported by complementary organizational structures and process management and that the form of Human Resource Management must be adapted to the demands of business strategy. However, for the authors, despite some flags, few companies practice strategic Human Resource Management.

\section{Human Resource Management as competitive advantage}

Per Becker, Huselid and Ulrich (2001), for the Human Resource Management area to strategically create value, it must be based on a managerial infrastructure that understands and can implement the organization's strategy, that is, the Typical services would normally happen, however, in a way that would directly support the implementation of the chosen strategy. While the focus of the organizational strategy is to create sustainable competitive advantage, the focus of the Human Resource Management strategy is to maximize the contribution to achieve the same goal, i.e., to choose the way in which its various management practices will be implemented.

Per Miles \& Snow (1984), there is a close articulation between Human Resource Management practices and organizational strategy, but different strategies require different types of people and management practices. In this way, how the organization interacts with the market directly influences the type of professional to be admitted and the behaviors to be stimulated within the organization. Mintzberg (2015) argues that the organizational structure is of fundamental importance for the effectiveness of organizational functioning, since it includes relations of authority and power, the way work is defined and its tasks, the coordination of the same and elements that guarantee consistency and External harmony. There is then a direct relationship between organizational structure and strategy.

In a general sense, for Miles \& Snow $(1978 ; 1984)$, organizations develop their adaptation strategies based on their own perception of the competitive environment. In this sense, strategic adaptation is a continuous strategic process and relates strategy, structure and processes. Companies develop relatively permanent patterns of strategic behavior that derive from three perspectives of interaction between organization and environment: (i) adjustment by natural selection (organization survives or dies due to environmental determinants); Ii) adjustment by rational selection (executives sufficiently capable of conceiving an optimal articulation with the environment) and iii) adjustment by strategic choice (environment is limiting, but allows executives to define their positions).

From these perspectives, a model was developed to explain the process by which an organization continually adjusts to the environment, which has been called the adaptive cycle, defined as the process experienced by companies when dealing with problems of three natures: business; Engineering and administrative. The business is to solve product-market issues, emphasizing the size of the company, efficiency, and innovation. The engineering department focuses on the choice of the best technology for production and distribution of the chosen products and services, and the administrative one, focused on reducing uncertainty, i.e. rationalizing and stabilizing activities 
to solve problems arising from business and engineering problems. The importance of solving administrative problems lies in its condition of formulating and implementing processes that allow the evolution of the organization (innovation) (MILES; SNOW, 1978). Facing this reality, these authors developed a typology of strategic behaviors that were classified into four categories: defensive, prospective, analytical, or reactive.

Defensive behavior seeks to maintain restricted domains for moderate and stable growth, protected by competitive prices or quality in products / services and therefore, organizations rarely need to adjust their technologies, structures, or operational methods. Conversely, they take the time to improve the efficiency of existing operations. Top managers are aware of their limitations in operations, however, they tend to seek new product opportunities outside of their domain. The characteristics of this profile include a limited product line, functional structure, development of production processes and product quality, cost reduction, low prices, and excellent customer service (MILES; SNOW, 1978). About Human Resource Management, they are based on internal development to keep employees for years, if not for their entire careers. They have an incentive system for bonuses and rewards, formulated to give everyone responsibility for both time and quality in production. Long-term development is rewarded with a slow but practically certain internal promotion. The key services offered by this profile are selection, allocation, evaluation, and assistance for long-term training. There is constant maintenance of the adjustment between job design and incentive system (MILES; SNOW, 1984).

Prospecting behavior is linked to the profile of organizations with aggressive competitive positions, continuously seeking new opportunities in the market and expanding the product or service line, and which regularly respond positively to trends emerging from the environment in which they operate. Generally, organizations present themselves as creators of changes and uncertainties, which competitors must respond to, seek pioneering, focus on innovation and not on efficiency. When the product reaches the stage where success depends on costs, attention is focused on the development of a new design or a new product. The risk of this strategy is considered high, since the non-acceptance of a new product by the public can mean considerable damages. Performance is evaluated per market share, sales volume, among others. The characteristics of this profile include a diversified product line, multiple technologies, divisional structure by product or geography, product research and development skills, market research and development engineering (MILES; SNOW, 1978). About Human Resource Management, talent is always required, inside and outside the organization and the rewards are based on responsibility. The Human Resource Management units of both the divisions and the main administration have the function of creating new teams, finding, and implementing technical and managerial resources. Thus, they have an entrepreneurial role, helping in the identification and development of essential people (MILES; SNOW, 1984).

The behavior analyst is related to the intermediate profile between the defensive and prospective strategies, the organization seeks to add to its line, products or services that are successful in other companies in the sector. Also, called "creative imitators", they absorb and improve innovations created by competitors, being leaders in product design and development, also competing for cost when needed. The design and marketing of the product are performed by the divisions and the processes of re- 
source allocation and product development are well monitored. They can transform the organizational structure and administrative processes to fit the different stages of the product life cycle. Analytical features include a limited line of products, search for a small number of market opportunities and / or related products, cost-effective technology for stable products, matrix structure, production efficiency skills, process engineering and marketing (MILES; SNOW, 1978). The differential is in the ability to acquire, train and allocate key people not only by products, but through different types of production processes, as well as assisting the organization's management in coordinating people (MILES; SNOW, 1984).

Finally, reactive behavior is linked to organizations that do not present a strategy, a coherent plan so that they can compete with other organizations or mechanisms to adapt to the market, that is, strategy, structure and processes are not aligned. Generally, they "wait to see" and respond to market stimuli when forced by competitive pressures, to avoid losing customers and continue to make profits (MILES; SNOW, 1978).

In demonstrating the relationship between strategy, structure, and Human Resource Management in the Canadian Pacific research, Miles \& Snow (1984) argued that the basic services provided by the Human Resource Management area are known to most organizations, the priority given to each and the way they are executed varies according to the organization's strategy, as shown in Table 2: 
Table 2 -The Evolution of the Human Resource Management System

\begin{tabular}{|c|c|c|c|c|}
\hline \multicolumn{5}{|c|}{ Evolution of the Human Resource Management system } \\
\hline & Agency & Functional & Divisional & Mixed \\
\hline $\begin{array}{l}\text { Role of the Human } \\
\text { Resource Management } \\
\text { system }\end{array}$ & $\begin{array}{l}\text { Informal } \\
\text { process }\end{array}$ & $\begin{array}{l}\text { Acquisition } \\
\text { Training } \\
\text { Maintenance }\end{array}$ & $\begin{array}{c}\text { Development } \\
\text { Consultant }\end{array}$ & $\begin{array}{l}\text { Planning } \\
\text { Allocation }\end{array}$ \\
\hline GP strategy & Inexistent & People development & Hire people & Place people \\
\hline $\begin{array}{l}\text { Emphasis in the } \\
\text { functional form }\end{array}$ & & $\begin{array}{l}\text { - Recruiting and } \\
\text { selection } \\
\text { Training and develop- } \\
\text { ment } \\
\text { performance valuation } \\
\text { Salary Management }\end{array}$ & $\begin{array}{l}\text { Recruiting and } \\
\text { selection } \\
\text { Training and develop- } \\
\text { ment } \\
\text { Performance valuation } \\
\text { Salary management }\end{array}$ & 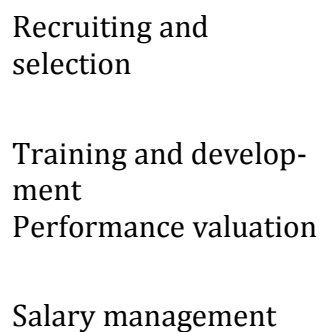 \\
\hline $\begin{array}{l}\text { Emphasis in the } \\
\text { divisional form }\end{array}$ & & & $\begin{array}{l}\text { Performance reward } \\
\text { HR Planning and } \\
\text { development } \\
\text { Position rotation } \\
\text { Planning of division } \\
\text { transference }\end{array}$ & $\begin{array}{l}\text { Performance reward } \\
\text { HR planning and } \\
\text { development } \\
\text { Position Rotation } \\
\text { Planning of division } \\
\text { transference }\end{array}$ \\
\hline $\begin{array}{l}\text { Emphasis in the } \\
\text { matrix form }\end{array}$ & & & & $\begin{array}{l}\text { Career planning } \\
\text { Evaluation centers } \\
\text { Organization } \\
\text { development } \\
\text { Competence } \\
\text { attributions }\end{array}$ \\
\hline
\end{tabular}

Source: Adapted from Miles and Snow (1984, p. 44).

The authors argue that in addition to basic services, a strategic Human Resource Management system can be constructed using the following design principles: people managers should be familiar with the concepts of all the services needed to acquire, develop, allocate and maintain professionals, although they emphasize some more than the others; Must have an understandable understanding of language and strategic planning practices; Should seek an appropriate strategy that matches the organization's strategy; Act as a professional consultant in order to align the units.

Research results from Miles \& Snow (1984) at Canadian Pacific showed that the group felt that the organization should take specific steps to maintain the strategic orientation of its approaches to Human Resource Management. First, the company's Human Resource Management group should continually evaluate policies and programs to determine which ones should be centralized and applied uniformly across all strategic business units and which should be decentralized to the various business management units. people. Secondly, the ability to aid the operational divisions should 
be developed to ensure that there is a link between Human Resource Management programs and business strategies, sufficient consistency to enable interdivisional Management talents and compliance with the legal requirements that the area demands. Finally, the group believed that the area should be organized and see itself as a business management consultancy capable of competing on an equal footing with other large consulting firms. To this end, a network of academic consultants and other specialists should be maintained for possible technical assistance. Table 3 shows the relationship between Human Resource Management services and the Miles \& Snow typology (1984):

Table 3 - Human Resource Management System

\begin{tabular}{|c|c|c|c|}
\hline & Defensive & Prospective & Analyst \\
\hline Organization structure & Functional & Divisional & Functional and Matrix \\
\hline Basic strategy & HR construction & HR acquirement & HR allocation \\
\hline \multirow{2}{*}{$\begin{array}{l}\text { Recruitment, selection and } \\
\text { allocation }\end{array}$} & Do & Acquire & Do and Acquire \\
\hline & $\begin{array}{l}\text { Low recruitment above the } \\
\text { entering level } \\
\text { Selection based in elimi- } \\
\text { nate undesired employees }\end{array}$ & $\begin{array}{l}\text { Sophisticated recruit- } \\
\text { ment in all levels } \\
\text { Selection could have a } \\
\text { psychological test }\end{array}$ & $\begin{array}{l}\text { Mix of approaches in re- } \\
\text { cruitment and selection }\end{array}$ \\
\hline Career Planning & $\begin{array}{l}\text { Formal } \\
\text { Extent }\end{array}$ & $\begin{array}{l}\text { Informal } \\
\text { Limited }\end{array}$ & $\begin{array}{l}\text { Formal } \\
\text { Extent }\end{array}$ \\
\hline \multirow[t]{2}{*}{ Training and developing } & ability construction & $\begin{array}{l}\text { Identification and acqui- } \\
\text { sition of abilities }\end{array}$ & $\begin{array}{l}\text { Construction and acquisition } \\
\text { of abilities }\end{array}$ \\
\hline & $\begin{array}{l}\text { Intense programs od train- } \\
\text { ing and developing }\end{array}$ & $\begin{array}{l}\text { limited programs of } \\
\text { training and developing }\end{array}$ & $\begin{array}{l}\text { intense programs of training } \\
\text { and developing } \\
\text { limited extern recruitment }\end{array}$ \\
\hline Performance evaluation & $\begin{array}{l}\text { Procedure oriented for } \\
\text { projects } \\
\text { Identification of people's } \\
\text { needs } \\
\text { individual and team per- } \\
\text { formance evaluation } \\
\text { Results compared by tem- } \\
\text { poral series }\end{array}$ & $\begin{array}{l}\text { Procedure oriented for } \\
\text { results } \\
\begin{array}{l}\text { Identification of people's } \\
\text { needs }\end{array} \\
\begin{array}{l}\text { Division or corporation } \\
\text { performance evaluation }\end{array} \\
\text { Transversal comparison }\end{array}$ & $\begin{array}{l}\text { Procedure oriented mainly } \\
\text { for projects } \\
\text { identification of personal } \\
\text { and formation necessities } \\
\text { Division or team perfor- } \\
\text { mance evaluation } \\
\text { Mainly temporal compari- } \\
\text { sons and a few transversal }\end{array}$ \\
\hline
\end{tabular}

Source: Adapted from Miles \& Snow (1984, p. 49).

Despite the efforts of Canadian Pacific and other organizations, not always the Human Resource Management area can proactively participate in the strategic planning process, conceptualizing, and helping in organizational design, to support and lead, when appropriate, the formulation of business strategies. 


\section{Methodological Procedures}

From a qualitative approach, the present research has a descriptive character, with a technical procedure to study multiple cases, based on the choice of three cooperatives in Paraná. The multiple case study is useful to better illustrate the problem studied and allows comparisons and relationships to be established, per Yin (2015), who emphasizes the importance of case selection. Therefore, in this research, the state of Paraná was chosen because it possesses the largest number of cooperatives and cooperatives in Brazil and the three cooperatives for leading billing and productivity rankings both at the state and national levels, per OCEPAR (2016).

Altogether, there were eight people who participated in the research, one being vice president, five are managers and two are in Human Resource Management. For respondents from areas not related to Human Resource Management, the criterion adopted was the minimum of eight years of cooperative so that it was possible to obtain the response of employees who had participated in the professionalization process or who had started in the cooperative at one time Next to the referent period. In one of the cooperatives there was no response from the Human Resource Management area. Table 4 presents the profile of the respondents:

Table 4 - Respondent Profiles

\begin{tabular}{l|l|l}
\hline \multicolumn{1}{c|}{ Cooperative } & \multicolumn{1}{c}{ Respondent } & \multicolumn{1}{c}{ Position or Function } \\
\hline$R$ & R-VP & Vice President \\
\hline $\mathrm{R}$ & R-GER & Agricultural manager \\
\hline $\mathrm{R}$ & R-GP & Human Resource Management Analyst \\
\hline $\mathrm{S}$ & S-GER I & Operation Manager \\
\hline $\mathrm{S}$ & S-GER II & Agricultural Business Manager \\
\hline $\mathrm{T}$ & T-GER I & Loan and Financial Manager \\
\hline $\mathrm{T}$ & T-GER II & Legal manager \\
\hline $\mathrm{T}$ & T-GP & Human Resource Management Manager \\
\hline
\end{tabular}

Source: research data

The data collection instrument was developed considering the characteristics of each typology proposed by Miles \& Snow (1978) and based on his work in the Canadian Pacific corporate group (MILES; SNOW, 1984), as summarized in the Tables 2 and 3. Thus, it was possible to construct statements that could be evaluated by the respondents using the Likert scale, making it easier to analyze responses. In the impossibility of a face-to-face application, web survey did the data collection, per Farias Filho \& Arruda Filho (2013), which consists in putting an online form with the appropriate link sending by email. Such a choice has the advantage of verifying information unknown to the respondent since the phenomenon to be studied occurred at least a decade ago, depending on the cooperative in question.

A pre-test was performed with two employees from the Human Resource Management area of other companies, which made it possible to adjust and improve the issues. Subsequently, during the analysis process, the need to clarify doubts 
about the answers was identified and the respondents were contacted, thus improving the understanding of the answers.

\section{Description and Analysis of results}

After a brief presentation of the history of each cooperative, the analyzed data will be shown, from the perspectives of the respondents, showing the points of contact and the discrepancies between the answers.

\section{Cooperative $\mathbf{R}$}

The first cooperative studied, called $\mathrm{R}$, specializes in the production and sale of dairy products, founded at the beginning of the 20th century by European immigrants who settled in a small town in the region of Campos Gerais in the state of Paraná. Initially, they found it difficult to sell their handmade products to meet the needs of the group, worked together to get better prices, setting up a small dairy industry in a cooperative format in the mid-1920s. Between the 1950s and 1960s, the union of three cooperatives in the region, with the purpose of organizing on a larger scale production, industrialization and trade of the products formed a central cooperative, the industry that was subordinated to the three unique cooperatives. In 1970, the group began operations in the meat (pork and poultry) market, and this diversification contributed to the consolidation of the brand as a large industrial complex, as well as investments that transformed the cooperative into one of the model organizations in the state of Paraná. In the late 1990s, it took an important step in entering agreements with a major competitor in the industry, with product diversification and exclusive launches. In the mid2000s, it passed the share control to another large meat company, reinforcing its strategy of expanding the brand and launching new products.

About the responses of the form on professionalization and the role of Human Resource Management, there was a discrepancy between the three respondents about which year could be considered the milestone of the professionalization of the cooperative. In view of this, it can be said that the professionalization began with some training and development policies in the year 2000, but it had a greater impulse with the stronger and clearer recognition of the need for professionalization between the years 2005 and 2007.

When asked if, during the period of professionalization, it was decided to hire new professionals or to invest in Training and Development programs, that is, if the cooperative preferred to build, acquire or allocate people, in a general way, it is perceived that The process began with the hiring of market professionals and then was invested in long-term training programs, as emphasized in R-VP's speech "[...] a strategic planning was developed and then defined the north, The paths to be covered and the means, hired qualified professional managers as well as the professionalization of the existing staff of the directors". The respondent also stated that the need for professionalization was felt by managers of top management, but also by producers and operating areas, including the area of Human Resource Management, although the area did not have the autonomy to make decisions regarding the process, indicating a pas- 
sive attitude, as presented by Miles \& Snow (1984) this is a common situation in organizations.

Regarding the Training and Development Programs, there is some disagreement among the answers about their duration. Although two of the three respondents pointed out that these programs had a short-term objective, when questioned about their duration, these same respondents pointed out that some programs have lasted for years, indicating that the cooperative may have started with a short-term objective, but throughout the execution of these programs, the need to extend them for a longer period may have been identified. Everything agreed, however, that they were focused on keeping existing employees, i.e. the focus was on developing their skills, characteristic of a defensive typology as well as analyst.

Regarding the Performance Evaluation, both individual and team evaluations were made (only the R-GER disagreed on the evaluation to be performed by teams). The monthly results were evaluated and compared, indicative of a time-series comparison (Table 3), and there is agreement that the procedures were oriented both to results, indicating a prospective and process posture, indicating a defensive posture or analyst. There was also identification of both personal and training needs, which indicates a more analytical stance on the part of the cooperative.

Regarding the services offered by the Human Resource Management area, during the period of professionalization, through the responses, it was observed that there was no implementation of services such as: "Rotation of Position", "Transfer of employees between divisions / units", "Career Planning" and "Evaluation Centers". These services, per Miles \& Snow (1984), emphasize an organizational structure in the divisional and matrix forms, characteristic of the prospective and analytical typologies, respectively. Thus, there is a greater presence of a functional structure, characteristic of a defensive typology. This type of organizational structure is also reinforced when the respondents indicate which structure best represented the cooperative during the period of professionalization.

On the questions directly related to identification of specific characteristics of the typology indicated by Miles \& Snow (1984), the presence of the three types of profile (Defensive, Prospective, and Analytical) was verified in the answers, according to Table 5:

Table 5 - Sum up of the Cooperative R responses

\begin{tabular}{l|c|c|c}
\hline \multicolumn{1}{c|}{ Questions } & \multicolumn{2}{c}{ Respondent } \\
\hline Rewards would vary due to the position & $\boldsymbol{R}$-VP & $\boldsymbol{R}$-GER & R-GP \\
\hline Intern professionals were relocated & $\begin{array}{c}\text { Agree partial- } \\
\text { ly }\end{array}$ & Totally disagree & Totally agree \\
\hline $\begin{array}{l}\text { Employees without the professional acquirements would } \\
\text { be fired }\end{array}$ & $\begin{array}{c}\text { Partially } \\
\text { agree } \\
\text { agree }\end{array}$ & Totally disagree & Totally agree \\
\hline External Contracting & $\begin{array}{c}\text { Totally Disa- } \\
\text { gree }\end{array}$ & Totally agree & partially agree \\
\hline
\end{tabular}

Source: research data. 
In relation to the differences pointed out in the previous table, in later contact with the respondents, it was noticed that there was both the external contracting and the development of existing employees, that is, acquisition and construction of new skills informed by Table 3, however that goes against the analytical profile of a limited external recruitment.

\section{Cooperative S}

It emerged in the early 1950s, with the arrival of European immigrants also in the Campos Gerais region of Paraná. A few years later, he joined the cooperative R and the other cooperative of the region forming the previously mentioned Central Cooperative. In the late 1990s, the three intensely connected colonies, with many kinship ties and common institutions that reaffirm the cooperative nature and proximity of these relationships, created the Corporation, currently one of the largest agroindustry of food production in Brazil, through a strategic association. However, in view of its strategic interests, the company S chose to leave its stake in the Corporation to invest in its own dairy industry. It has a strategic vision of investment in agricultural research and development that indicates an important competitive differential. Cooperative $\mathrm{S}$ works in other sectors other than agriculture, such as swine farming, beef cattle and sheep farming.

With regard to the answers about the process of professionalization of the cooperative $S$, it was also possible to observe that there was a discrepancy on what was the year to be considered the milestone of the professionalization of the cooperative. While the S-GER I pointed out that the process began in 1995 through outsourcing and organizational culture training programs that directly contributed to the achievement of business results, S-GER II noted that this occurred In 2005, a year in which the cooperative more consistently implemented Strategic Planning and corporate governance concepts, in addition to the professionalization of management in a general way, a need perceived by the managers of the cooperative, but partly by the operational and producer areas. It is understood, therefore, that professionalization can be understood as a process composed of different stages, being in the initial stage more important the coming of external professionals and in a second moment, the structuring and formalization of a strategic planning become possible and impel new measures of professionalization.

Due to the different understanding of when the process of formalization began, S-GER I attributes more impact to external contracting and training and development programs. For S-GER II, the main driver was formal strategic planning. Following the concept of Basic Strategy presented in Table 3, the former believes that there was an emphasis on acquiring professionals (hiring new ones) and, for the second, there was an emphasis on building the group of professionals, to professionalize the management of the cooperative.

On these Training and Development Programs, it was observed that they lasted for both weeks and years, which shows a focus on an extensive training program, characteristic of the typology of Miles \& Snow (1984), both defensive and analytical. Although S-GER I disagree that this was the cooperative's goal when it implemented them. He also disagrees that the purpose of the program was to keep existing employees, 
which indicates a prospective feature of the company. This response is different from that presented by S-GER II, who believes that the purpose of the program was rather to retain existing employees. This divergence of opinions, as previously mentioned, may be related to the difference with respect to the time of professionalization of the cooperative. In relation to the Performance Evaluation, it was noticed that there was a greater agreement that the evaluations were carried out through the Business Units, as shown in Table 6:

Table 6 - Answers about the cooperative S evaluation

\begin{tabular}{l|l|l}
\hline \multicolumn{1}{c|}{ Questions } & \multicolumn{2}{c}{ Responses } \\
\hline The evaluation process was individual & Neither agree nor disagree & \multicolumn{1}{c}{ S-GER II } \\
\hline Teams did the process evaluation & Neither agree nor disagree & Totally disagree \\
\hline Business units were evaluated & Partially agree & Totally agree \\
\hline
\end{tabular}

\section{Source: research data.}

It should be noted that for S-GER II there was also a focus on the individual evaluation, which, together with the evaluation by Business Units, is characterized by an analytical typology by Miles \& Snow (1984), but considering the S-GER response I, there was a greater focus on a division evaluation, characteristic of a prospective typology. When asked if the processes and / or results were evaluated, S-GER I did not agree with either of the two questions and S-GER II agreed with both. However, there was a consensus that Performance Evaluation programs focused on both the identification of employees' personal needs and training needs, characteristic of the analyst typology.

Regarding the services offered by the Human Resource Management area during the professionalization period, the presence of the prospective profile is generally perceived, since there are actions and services performed by the company that emphasize the Divisional form, characteristic of a profile Prospective. The answers to the questions, directly related to identification of specific characteristics of the typology indicated by Miles \& Snow (1984), demonstrate the presence of all three typologies, since there was no disagreement in all the related questions.

\section{Cooperative T}

Also, an agroindustrial cooperative of the state of Paraná, the cooperative T began with the participation of less than 80 farmers, in 1970, was located first in a city of the north region of Paraná. Created as the solution to several problems of producers in the region who needed to create a mechanism that would enable production and marketing, industry leaders were identified and the first headquarters was inaugurated. Constantly in search of internal expansion, the construction of new establishments and an own market were the strategies most used by the cooperative from the beginning of its activities until the end of the 1970s, when the first expansion occurred through acquisitions of other companies. At the end of the 1980s, through a vertical integration, 
a rural credit cooperative was created to support and finance the rural activities of the members. Affirming the desire for continued growth, it acquired a port terminal in Paranaguá in 1990, thus allowing the export of products, a process that demands knowledge, which represents one of the resources of the firm, being the result of a previously planned administrative process. Currently, it has more than 100 units located in 68 municipalities that go beyond the borders of Paraná, in Santa Catarina and Mato Grosso do Sul. It is currently one of the largest cooperatives in Brazil and accounts for $3.6 \%$ of the country's agricultural production. Soybean, followed by corn, wheat, coffee, and others.

There is also disagreement among the interviewees about the period of professionalization of cooperative $\mathrm{T}$. The difference is related to the T-GER I response that the professionalization process occurred in the 2000s, while for the other two, professionalization took place in the 1980s When asked if the process of professionalization of the cooperative was marked by the hiring of new employees or by the implementation of Development and Training Programs, there was a consensus that new hires were necessary in the period, but that there was also an appreciation of the cooperative's internal experiences. According to Table 7 below, it is possible to notice that the answers present similarity on questions related to the Training and Development Program implemented during the professionalization period of the cooperative:

Table 7 - Responses about the Training and Development - Cooperative T

\begin{tabular}{l|l|l|l}
\hline \multicolumn{1}{c|}{ Questions } & \multicolumn{1}{c|}{ T-GP } & \multicolumn{1}{c}{ T-GER II } & \multicolumn{1}{c}{ T-GER I } \\
\hline The aim is to teach new abilities to old employees & totally agree & partially agree & totally agree \\
\hline $\begin{array}{l}\text { the employee evaluation was done before the implantation } \\
\text { of programs }\end{array}$ & $\begin{array}{l}\text { partially } \\
\text { disagree }\end{array}$ & totally agree & totally agree \\
\hline abilities cannot be developed in training & totally disagree & totally disagree & totally disagree \\
\hline The program did not accept the demand of abilities & totally disagree & totally disagree & totally disagree \\
\hline The program's aim is the maintenance of employees & $\begin{array}{l}\text { Neither agree } \\
\text { nor disagree }\end{array}$ & partially agree & totally agree \\
\hline
\end{tabular}

\section{Source: research data.}

This alignment may be related to the cooperative prioritizing skill building during the Training and Development Program implemented at the time of professionalization, since it aimed to teach new skills to older employees and there was no disagreement that it aimed to maintain these skills. Instead of hiring new ones that, per Miles \& Snow (1984), are characteristic of a defensive profile. Regarding the duration of these programs, indicated by Table 8 , it is observed that, in general, the programs had a long-term objective and that they lasted for both weeks and years. This indicates a characteristic both defensive and analytical of the company: 
Table 8 - Responses about the training and development program

\begin{tabular}{l|l|l|l}
\hline \multicolumn{1}{c|}{ Questions } & \multicolumn{3}{c}{ Interviewed } \\
\hline The programs had short term aims & \multicolumn{1}{c}{$T$-GP } & \multicolumn{1}{c}{$T$-GER II } & \multicolumn{1}{c}{$T-G E R I$} \\
\hline Some programs lasted weeks & $\begin{array}{l}\text { Neither agree nor } \\
\text { disagree }\end{array}$ & totally disagree & totally disagree \\
\hline Some programs lasted months & totally agree & totally disagree & totally agree \\
\hline Some programs lasted years & totally agree & partially disagree & totally agree \\
\hline
\end{tabular}

Source: research data.

Regarding the Performance Evaluation carried out by the cooperative T, it was possible to note that it was a formal process and that it evaluated the necessary training requirements for the positions and the personal needs of the employees, both indicative of an analytical typology. The evaluations were carried out individually, not by teams, which also indicates a characteristic analyst of the cooperative.

There is also the presence of an organizational structure with a "functional" character during the period of professionalization, it is observed that the functional structure was present during the period of professionalization, but there is no definition if the "divisional" and "matrix" Since there is disagreement as to whether services and actions such as "Evaluation Center", "Organizational Development" and "Task assignments by competency" were present and actions and services such as "Rotation" and "Performance Rewards" were not present in the period. This is indicative of a defensive profile.

On questions directly related to the characteristics of the typology of Miles \& Snow (1984), there is presence of the defensive profile, being only general disagreement in questions like the company "Had a System of bonuses and rewards"; "Employees who did not have the professional requirements were dismissed" and "Process relied on the construction of a formal career planning". There was no external contracting prioritization, characteristic of a prospective profile, that is, the cooperative did not prioritize to hire new professionals in the labor market, and it relocated professionals between the areas during the professionalization process, however, new teams were not formed after the process.

\section{Conclusion}

The results show that the three cooperatives studied presented strategic behavior with defensive and, to a lesser degree, analytical and prospective characteristics regarding the strategies of the changes in the market that evolved, offering better products and more competitive prices, forcing cooperatives to improve their Infrastructure and processes through professionalization. It was difficult to score exactly when the process started in each cooperative, which means that different initiatives were taken at different points towards professionalization and that this was not a clear and formal decision or was not properly communicated and institutionalized. 
The Human Resource Management strategies of the cooperatives, initially, were to seek professionals in the market and train and develop existing employees to the skills needed for the new structure. Two cooperatives, $\mathrm{R}$ and $\mathrm{T}$, have functional structure while cooperative $\mathrm{S}$ has some divisional structure characteristics and these forms of structure conditioned some choices and actions of the Human Resource Management area, corroborating the studies of Miles \& Snow (1984) of which strategy and structure are related and influencing one another.

It is concluded that the Human Resource Management area participated in the professionalization process, but in a partially autonomous way. From the perspective of managers from unrelated areas, the Human Resource Management area played an important role in the process, maintaining the employees through training and also in the selection of new talent, but attending to the requests of the managers and not anticipating to the demands. It is also noted that the Human Resource Management area encompasses performance evaluation activities, but presents processes that must be improved or put into practice to encourage the continued professionalization of the cooperatives studied. In this way, analyzing from Miles \& Snow (1984), the approach of the Human Resource Management area of cooperatives contributed, in a general way, to a strategic defensive posture, that is, it seeks to act from the demand of the Managers to improve the efficiency of existing operations, preserving the cooperative ideology, developing internal talents and the foundations that unify the cooperative.

The demand for professionalization came from the professional managers of the cooperatives, followed with less emphasis by the cooperatives and employees in more operational functions. This fact demonstrates the difference of perception regarding the management and the ways of acting in a competitive environment, since the cooperative owners, although they are owners and have voice and vote in the organizational decisions, seem to be more oriented towards the production and commercialization of their products And less involved with the strategic management of the cooperatives as a whole, which demands proactivity by the professional managers and also the management support areas, as is the case in the area of $\mathrm{Hu}$ man Resource Management.

Given that cooperatives started to interact with the market, thus, resembling organizations that already have this competence, it is suggested that the role of the Human Resource Management area be rethought by the management of agricultural cooperatives, to provide more space for the professionals of the area participate in the planning and strategic decisions, besides showing their role with the cooperative. At the same time, it is necessary that professionals in Human Resource Management also seek specific knowledge about the competitive dynamics of agribusiness, in order to collaborate with the alignment between organizational strategies and the policies and actions of selection, evaluation and retention of professionals to work in cooperatives.

A contribution of this work was to broaden the spectrum of application of the Miles \& Snow (1984) typology to the strategies of Human Resource Management, considering as a locus of research a cooperative environment that presents a series of different environmental conditions of other organizations, by its own characteris- 
tics, such as diffuse property, democratic adherence and fostering of cooperative education.

\section{References}

ANTONIALLI, L. M.; SOUKI, G. Q. Princípios cooperativistas e modelo de gestão: um estudo sobre conflitos de interesses entre grupos de produtores rurais. XLIII CONGRESSO DA SOBER. Ribeirão Preto, 24 a 27 de Julho de 2005. Sociedade Brasileira de Sociologia e Economia Rural. Anais...2005

BARNEY, J. B.; HESTERLY, W. S. Administração estratégica e vantagem competitiva. - São Paulo: Pearson Prentice Hall, 2007.

BECKER, B. E.; HUSELID, M. A., ULRICH, D. Gestão de Pessoas com Scoredcard: Interligando Pessoas, Estratégia e Performance. Ed. Campus, 2001.

BIALOSKORSKI NETO, S. Agronegócio Cooperativo. In: Gestão Agroindustrial: BATALHA, M. O. (Coord). 3.ed. - 7. Reimp. p. 711 - 734. - São Paulo: Atlas, 2013.

BIALOSKORSKI NETO, S.; MARQUES, P. V. Agroindústria cooperativa: um ensaio sobre crescimento e estrutura de capital. Revista Gestão e Produção, São Carlos, v. 5, n. 1, p. 60-68, 1998.

DAVIS, P.; BIALOSKORSKI NETO, S. Governança e gestão de capital em cooperativas: uma abordagem baseada em valores. ESAC - Economia Solidária e Ação Cooperativa. Unisinos, v.5, n.1, p.01-24, jun/jun 2010.

FARIAS FILHO, M. C.; ARRUDA FILHO, E. J. M.: Planejamento da pesquisa científica. São Paulo: Atlas, 2013.

FLEURY, M. T. L.; FLEURY, A. Construindo o Conceito de Competência. RAC - Revista de administração Contemporânea, Edição Especial, p. 183 - 196, 2001.

HANSMANN, H. The ownership of enterprise. The Belknap Press of Harvard University Press, 1996.

HENDERSON, B. D.; As Origens da Estratégia. In MONTGOMERY, C. A; PORTER, M. E. Estratégia: a busca da vantagem competitiva. 10ª Reimpressão. Rio de Janeiro: Elsevier, 1998.

HOSKISSON, R. E.; HITT, M. A.; IRELAND, R.D.; HARRISON, J. S.; Estratégia Competitiva. São Paulo: Cengage Learning, 2009.

IRELAND, R. D.; HOSKISSON, R. E.; HITT, M. A. Administração Estratégica. São Paulo: Cengage Learning, 2014.

MILES, R. E.; SNOW, C. C. Organizational strategy, structure, and process. New York: McGrawHill, 1978.

MILES, R.; SNOW, C. Designing Strategic Human Resource Systems. Organizational Dynamics, 13(1), Summer, 36-52, 1984.

MINTZBERG, H. Criando Organizações Eficazes: Estrutura em Cinco Configurações. 2a ed. 9a reimpressão. São Paulo: Atlas, 2015.

OCB. Organização das Cooperativas Brasileiras. Disponível em http://www.brasilcooperativo.coop.br/site/ramos/agropecuario_numeros.asp. Acesso em 15 set. $2016 \mathrm{a}$. 
OCB. Organização das Cooperativas Brasileiras. Relatório de Gestão OCB - 2015. http://www.brasilcooperativo.coop.br/GERENCIADOR/ba/arquivos/relatorio_de_gesta_ocb_ 2015_impresso.pdf. Acesso em 15 set. 2016b.

OCEPAR. Organizações das Cooperativas Paranaenses. Informe Paraná Cooperativo - Gestão: Sescoop/PR discute a importância da excelência da gestão, 2016. Disponível em: http://www.paranacooperativo.coop.br/ppc/index.php/sistema-ocepar/comunicacao/201112-07-11-06-29/ultimas-noticias/109692-pdgc. Acesso em: 15 set. 2016.

POLONIO, W. A. Manual das sociedades cooperativas. 4ed. São Paulo: Atlas, 2004.

RECH, D.; Cooperativas: uma alternativa de organização popular. Rio de Janeiro: Fase e DP\&A, 2000.

SILVA, E. A.; PEREIRA, J. R.; BOTELHO, M. I. V.; A organização cooperativa e seus princípios democráticos. Revista Organizações Rurais \& Agroindustriais, Lavras, v.7, n.2, p. 135-147, 2005.

TRINDADE, L. Z; BIALOSKORSKI NETO, S. Uma análise da separação entre a propriedade e a gestão nas cooperativas de crédito brasileiras. Revista de Contabilidade e Organizações, v. 6, p. 95-118, 2012.

ULRICH, D. Os Campeões de Recursos Humanos: Inovando para Obter os Melhores Resultados. Futura, São Paulo, 1998.

YIN, R. K. Estudo de caso: planejamento e métodos. 5. ed. Porto Alegre: Bookman, 2015.

ZYLBERSZTAJN, D. Organização das cooperativas: desafios e tendências. Revista de Administração, São Paulo, v.29, n.3, p.23-32, jul/set. 1994.

Received: 09/30/2016

Approved: 01/24/2017 